\title{
Organisational leadership, women and development in the Apostolic Faith Mission in Zimbabwe: A practical theology perspective
}

\begin{tabular}{|c|c|}
\hline \multicolumn{2}{|c|}{$\begin{array}{l}\text { Authors: } \\
\text { Joachim Kwaramba }{ }^{1} \\
\text { Yolanda Dreyer }\end{array}$} \\
\hline $\begin{array}{l}\text { Affiliations: } \\
{ }^{1} \text { Religious Stu } \\
\text { and Philosoph } \\
\text { Zimbabwe, } \mathrm{H}\end{array}$ & $\begin{array}{l}\text { es Classics } \\
\text { University of } \\
\text { re, Zimbabwe }\end{array}$ \\
\hline $\begin{array}{l}{ }^{2} \text { Department } \\
\text { Theology, Fac } \\
\text { University of } \\
\text { Pretoria, Sout }\end{array}$ & $\begin{array}{l}\text { ractical } \\
\text { Ity of Theology, } \\
\text { retoria, } \\
\text { Africa }\end{array}$ \\
\hline $\begin{array}{l}\text { Research Proj } \\
\text { Project Leade } \\
\text { Project Numb }\end{array}$ & $\begin{array}{l}\text { ct Registration: } \\
: \text { Y. Dreyer } \\
\text { er: } 2546930\end{array}$ \\
\hline $\begin{array}{l}\text { Description: } \\
\text { This research i } \\
\text { project, 'Gend } \\
\text { Practical Theo } \\
\text { Formation', dir } \\
\text { Dr Yolanda Dre } \\
\text { of Practical Th } \\
\text { of Theology ar } \\
\text { University of P }\end{array}$ & $\begin{array}{l}\text { part of the } \\
\text { r Studies and } \\
\text { ogy Theory } \\
\text { ected by Prof. } \\
\text { yer, Department } \\
\text { ology, Faculty } \\
\text { d Religion, } \\
\text { etoria. }\end{array}$ \\
\hline $\begin{array}{l}\text { Correspondin } \\
\text { Yolanda Dreye } \\
\text { yolanda.dreye }\end{array}$ & $\begin{array}{l}\text { author: } \\
\text { r, } @ \text { @up.ac.za }\end{array}$ \\
\hline $\begin{array}{l}\text { Dates: } \\
\text { Received: } 21 \\
\text { Accepted: } 15 \\
\text { Published: } 29\end{array}$ & $\begin{array}{l}\text { eb. } 2019 \\
\text { uly } 2019 \\
\text { Nov. } 2019\end{array}$ \\
\hline $\begin{array}{l}\text { How to cite tl } \\
\text { Kwaramba, J. } \\
2019 \text {, 'Organi } \\
\text { leadership, w } \\
\text { development } \\
\text { Faith Mission } \\
\text { A practical th } \\
\text { perspective', } \\
\text { Studies/Theol } \\
75(1), \text { a5436. } \\
\text { 10.4102/hts.v }\end{array}$ & $\begin{array}{l}\text { is article: } \\
\text { \& Dreyer, Y., } \\
\text { ational } \\
\text { men and } \\
\text { n the Apostolic } \\
\text { n Zimbabwe: } \\
\text { ology } \\
\text { TS Teologiese } \\
\text { gical Studies } \\
\text { tttps://doi.org/ } \\
\text { 75i1.5436 }\end{array}$ \\
\hline $\begin{array}{l}\text { Copyright: } \\
\text { (C) 2019. The } \\
\text { Licensee: AOS } \\
\text { is licensed un } \\
\text { Creative Com } \\
\text { Attribution Li }\end{array}$ & $\begin{array}{l}\text { uthors. } \\
\text { S. This work } \\
\text { ler the } \\
\text { nons } \\
\text { ense. }\end{array}$ \\
\hline 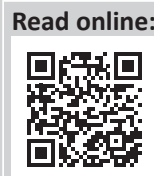 & $\begin{array}{l}\text { Scan this QR } \\
\text { code with your } \\
\text { smart phone or } \\
\text { mobile device } \\
\text { to read online. }\end{array}$ \\
\hline
\end{tabular}

This article focusses on women and the organisational leadership structures of the Apostolic Faith Mission (AFM) in Zimbabwe. The aim is to identify the roles, practices and contributions of women to the developmental agenda in the church. The AFM in Zimbabwe identifies leadership positions in their various assemblies as pastor (mufundisi), elder (muvhangeri), deacon (muparidzi) and lay worker (mubati). From these ranks, the provincial and national leadership is chosen. The access to and participation of women in these offices and leadership positions will be investigated to ascertain their input to the development of the church and perception of women in the society. The article discusses the mechanisms for the election of leadership in the AFM in Zimbabwe. It analyses leadership succession and leadership roles within the AFM in Zimbabwe from the perspective of gender equity and the involvement (or lack thereof) of women in policy-making, decision-making and the management of the church. Four aspects of the Exploratory Descriptive Normative Action research (EDNA) model were utilised from a practical theology perspective. The article shows that women do not have access to top leadership positions in the AFM in Zimbabwe even though there are no explicit policies that regulate their exclusion. It highlights their contribution to the development of the church despite this exclusion and engages critically with the unspoken assumption that women are not fit to take up the presidium offices and develop the AFM. The article finds that unquestioned patriarchal discourse contributes to women's invisibility, which results in their not being taken into consideration when choices are made to elect people for higher leadership positions in the church.

Keywords: Women; Gender; Church leadership; Practical theology; Pentecostal.

\section{Leadership}

Leadership is an ancient art as civilisations continue their efforts not only to survive but also to advance (Titus 1950:xi). Early descriptions of leadership have come from practice, from a perspective of hands-on leadership experience. In the process of defining leadership, certain challenging questions emerge (see Posner 2002:86).

One such question is: How does one explain the upward mobility of one section of the members of a society or an organisation, whereas others remain stationary or move upwards only for a short period of time? This question is also relevant to churches as an organisation. Another question pertinent to this investigation concerns the phenomenon that some people can attain a dominant position in a fairly short period of time, whereas others remain followers in the lower ranks of the organisation.

For a society or community to exist and thrive, some form of leadership system is necessary. Leadership is necessary for an organisation to achieve its objectives. The Apostolic Faith Mission (AFM) in Zimbabwe is both an organisation and a community. It has a structure and therefore requires leadership on different levels, from local assemblies to the national and international levels. The aim of the article is to explore the leadership system of the AFM in Zimbabwe to ascertain the measure of the acceptance of or resistance to women in higher offices and leadership positions. This has definite implications for the development of the organisation. The article argues that no meaningful development is possible without the active involvement of women and the utilisation of their gifts, talents and skills on all levels of society, communities and the church.

Note: The collection entitled 'Christina Landman Festschrift', sub-edited by Wessel Bentley (University of South Africa) and Victor S. Molobi (University of South Africa).

This article represents reworked aspects of the PhD-thesis of Joachim Kwaramba, titled, 'A practical-theological perspective on female leadership in a Pentacostal context in Zimbabwe', completed under the supervision of Prof. Dr Yolanda Dreyer, Department of Practical Theology, Faculty of Theology and Religion, University of Pretoria. 
In order to come to a useful description of leadership, the terms 'lead' and 'leader' will be unpacked. A problem with language is that people and cultures often attach very different connotations to terms and words.

The word 'lead' can have the connotation of power and dominance to some, whereas to others, it can have the connotation of service and the nurturing of others to develop to their full potential. Church leadership does not only entail standing in front of (leading) a congregation but is also about influencing people to do and achieve something. According to Luke 22:26, Jesus said: 'Let the greatest among you become as the youngest and the leader as one who serves'. This gospel perspective on leadership entails that it is not about demanding obedience from others. It is rather about moving things forward towards a goal. Anyone, any sex, male or female, can and should fully contribute to that goal with all the God-given gifts and talents at their disposal.

Leadership should therefore not be seen as the dominant prerogative of men, but as the calling of all who are so gifted. From such a perspective on leadership, it is for those who are mature, not in years, but in attitude or disposition. If men are not mature, they should not be leaders. If women are mature, there should be no impediment to their leadership. People with a mature disposition will necessarily understand leadership as service to those who are led, facilitated and nurtured for growth and a productive contribution to the whole.

Leadership and development are about taking moral and spiritual responsibility.

\section{Leadership in the Apostolic Faith Mission in Zimbabwe}

The leadership of the AFM in Zimbabwe is described in the Constitution of the church. The development of the church is also attended to in the same Constitution. Those who make themselves available for a leadership role should fulfil the requirements and adhere to the regulations. Qualifications required are: seniority, the length of time the person has been a church member, kinship and inheritance (Daneel 1989:253). Novices are not eligible for leadership positions because the church requires of its leaders to have a depth of knowledge and experience of the legacy of the church. In the election of leaders for the AFM in Zimbabwe, factors that are of particular importance are the involvement of the Holy Spirit, seniority, expertise and experience. These will now be briefly discussed.

The AFM in Zimbabwe submits to the power and influence of the Holy Spirit in both its operation and belief system. The development of this aspect can be traced through in three phases of the church's history. According to a former leader of the church, the Reverend S. Mutemererwa, leaders are selected after much prayer and 'yielding to the Holy Spirit'. This 'yielding' is performed by all church members through prayer and seeking the guidance of the Spirit. Although prayer and yielding to the Holy Spirit is of such central importance, there is, of course, also a distinctly human factor in the election of leadership. People make the final decision by casting lots. This electoral process is not exempt from human involvement and even human error. The exclusion of a major section of the church population with all the gifts and talents granted to them by God, from the opportunity to be elected, namely, women, can well be such a human error. However, the end result of the selection is confidently announced as the work of the Holy Spirit. This is a key component to the development of the leadership in the AFM in Zimbabwe.

Former president Mutemererwa pointed out that especially in the early years of church-planting in Zimbabwe, leadership yielded to the Holy Spirit for the day-to-day activities of the church with much dedication. His own experience with the power of the Holy Spirit was narrated in terms of two personal encounters. He told the story of how he would travel in the Chivi district, a rural area in Zimbabwe's Masvingo province, and preach the gospel. In his travels and preaching, he experienced the guidance and protection of the Holy Spirit. He once encountered a male lion on the path he was taking. He spoke to the lion to let him pass and invoked the help of the Holy Spirit. The lion let him pass without a problem. The second story pertains to how women were first ordained in the church under his leadership when he served as the president in 1999. He explained that he as a leader had heard from the Holy Spirit that women should be ordained and he complied. Though he faced much resistance, his insistence that the Holy Spirit was the initiator of the process silenced the opposition.

Although women could since be ordained as pastors in the AFM in Zimbabwe, their daily lives and work are still affected by African cultural norms and taboos. These often hold that the role of women is second to that of men.

Experience and the length of time that they have served in the church are important criteria when it comes to the election of leaders. This is explained in the Constitution. The Constitution states that an elder 'must be at least thirty years of age, spiritually mature and has served at least three years as a deacon without having been disciplined during that time' (Apostolic Faith Mission in Zimbabwe Constitution and Regulations 1996:20). Seniority, experience and expertise expected of top leadership, such as an overseer or a president, are attained by means of a continuity of leadership service through the ranks from deacon to elder and beyond. The Reverend C. Chiangwa explained that one does not necessarily have to be a senior for all leadership offices, but for some offices, seniority and expertise are high priorities. For instance, even if a person has seniority and long-term experience but has been fairly passive, the probability of that person being chosen to lead would not be high. There is a specific procedure laid down in the policy with regard to the election to a leadership office. After an acceptable period of service in the church, a person can be recommended by their 
pastor for being vetted for a key leadership office. In this process, practice has shown that women are not often mentored or recommended by pastors. They remain invisible while men, even though more inexperienced than women, are groomed and recommended, irrespective of their lack of gifts or qualities.

Women in the assembly perform the roles prescribed to them by the local church board. Most of the work performed by women in the church is voluntary, not paid employment. This work is performed by people who wish to serve God in some way. According to the Reverend E. Gweshe, a woman can remain a secretary to the pastor if she is able to write or she can lead the choir and if she has musical ability. Leadership potential is considered when electing a leader, because leadership skills are developed over time. A person shows that potential can be chosen for leadership even though the person does not yet have a proven track record. According to the Reverend C. Chiangwa, moral uprightness is of the utmost importance when electing a person to a leadership position in the church. If a bishop or leader were to commit a transgression, the matter would be investigated and, depending on the findings of the panel, the person would be suspended or disciplined. The discipline could entail the removal of the person from the leadership office in which he or she was serving. The marital status and lifestyle of the person would be another pre-requisite for selection to leadership. This is based on 1 Timothy 3:12, 'let deacons be husband of one wife'. In this letter, the language indicated that only male persons were deacons at the time. In African Independent Churches (AICs), for instance, both age and marital status contribute to the eligibility of a person to become a leader (see Powers 1979:53). This is also the case in the AFM in Zimbabwe where mostly married men are chosen as leaders for the highest offices in the church. The preferred candidates for the top positions have hitherto all been male.

To qualify for the position of the overseer, a person should have completed 10 years of service in the church. The Constitution puts it as follows: 'A provincial Overseer must have been an ordained pastor of the AFM in Zimbabwe for a minimum of ten years with a proven record' (AFMConstitution 9.3.1, p. 24). Although this clause is not gender-specific, the attention is automatically focussed on male candidates, because of the patriarchal and cultural mindset according to which a female is not considered for leadership in key positions. Technically, ordained women with 10 years of experience in pastoral ministry in the church (which is now a possibility) could qualify as a candidate for the position of overseer. However, in practice, this does not happen. Women are ignored when it comes to selection for this key provincial position. The unwritten and unspoken assumption seems to be that women cannot be influential in the management and development of the church. The patriarchal scissors 'trims their wings' and keeps them from soaring. They are confined to the 'lower echelons' of local assemblies.

When the position of the overseer is explained in the Constitution, the exclusive male language is conspicuous: '[h]e must have a Diploma in Theology and qualify according to 1 Timothy ...' (AFM Constitution 9.3.2, p. 25).

Through this kind of language, the gender question arises. The church, without reason or explanation, just obviously expects a male candidate when it comes to the position of the overseer. The exclusive male language continues: 'The minimum age must be forty years, retirement age maximum of sixty-five years. He shall serve in the office as long as he is elected' (AFM Constitution 9.3.3, p. 25). In this clause, the minimum age that is stated would also mean that the candidate for this position would be mature enough to make informed decisions and provide productive advice through experience. In actual fact, either sex could be competent and eligible for this. However, the Constitution clearly exhibits a gender bias and in effect excludes women.

Inheriting the legacy of a father who had been a leader is another way for a person to be regarded as an adequate candidate for leadership. This is common to many AICs. Leadership is hereditary in that it follows the traditional concept of wabara wamuka (you rise through your offspring).

Usually, leadership is passed on from father to son. Regardless of its Constitution, the AFM in the 21st century is not exempt from such practices. Some families feature heavily in the church's leadership. These names carry much respect in the church. If a father was once a leader, either as a provincial overseer or the president, his children who become pastors are likely to be chosen for leadership positions. This again causes women as possible candidates to fall by the wayside because this practice favours the male heritage.

\section{The leadership structure}

The leadership structure of the AFM in Zimbabwe is composed of, from lower to the highest level, deacons and elders, pastors, overseers and the president. For the AFM in Zimbabwe, constitutionally, grassroots leadership is situated mainly in the local board of elders. This gives a significant amount of power to the 'lay' component of the system, in other words those without formal theological training. In this structure, the ordained pastor becomes part of a team of seven members. The pastor does not have the autonomy to decide the development of the church alone. The views of the elders and deacons from the assembly leadership are the deciding factor. At the national level in the Apostolic Council, however, the elders have little decision-making power because they are outnumbered by the overseers who are ordained pastors. The higher leadership structure consists mainly of overseers, with only one elder who is the national administrator. All the overseers are ordained ministers. This hierarchy is now briefly explained.

Deaconesses, deacons and elders in the AFM in Zimbabwe cannot be new converts in the church. These are the 'lay workers'. Ordained ministers, on the other hand, are the 'full-time workers' (Constitution Chapter 15, p. 14). The duties of the deacons and elders are regulated by the Constitution. 
The full-time employees are made up of probationer pastors, ordained pastors and emeritus ordained pastors. They are certified by the Apostolic Council according to the provisions of the Constitution. The Constitution of the AFM in Zimbabwe states that the deacon or elders are elected when the local board of elders '.. annually submit names of the candidates to the annual General Council for recommendation. The names shall then be submitted to the Provincial Council for investigation and appointment' (Constitution 4.1.1, p. 19). The names of those who succeed are then forwarded to the provincial secretary for the issuing of credentials.

\section{According to the Constitution (15.3.1):}

$[T]$ he elders may preach and conduct services, baptize believers, lay hands on and pray for the sick, bury the dead, consecrate children when authorised by the pastor or overseer, administer the Lord's Supper. (p. 32)

The deaconesses are authorised to pray for the sick, as well as assist with the physical and temporal care of members of the church and the community. They pray for the sick and conduct other spiritual activities at the pastor's discretion (Constitution 15.1, p. 31). On the other hand, the deacons in the AFM in Zimbabwe help with the administration of the church, as well as with the physical and temporal welfare of the members of the church and the community. They may also preach, conduct services and pray for the sick at the discretion of the board of elders and the guidance of the Holy Spirit (Constitution 15.2.1, p 31). On a grassroots level, the lay workers have decisive power because they constitute the majority of the church board. Clause 15.2.1 of the Constitution states that their guidance does not come from the pastor but from the Holy Spirit. However, when it comes to the leadership of women as deaconesses, they seem to be guided by the pastor rather than by the Holy Spirit.

To become a pastor, any person can apply for training at the Bible College if they have been endorsed by the board of elders of their local church. This provides a measure of control to ensure that a complete stranger or novice in the AFM will not be accepted to the Bible College as a potential pastor in the church. This also places the power of endorsement in the hands of elders. Should they have a problem with female pastors, it can be a problem for a woman, however, much she feels called by the Holy Spirit, to procure the necessary endorsement. Pastors are considered 'full-time workers' in the AFM in Zimbabwe. The Constitution states that 'the pastor shall be an ex-officio chairperson of the Assembly Board, all committees and all departments in the assembly' (Constitution 15.4:32). The pastor, together with the Assembly Board, manages the affairs of the Assembly. The pastor is seen as the shepherd and the leader of the assembly.

Each province in the AFM in Zimbabwe elects an Overseer during their council meeting. The requirement is equal representation from the assemblies. The overseer presides over all provincial meetings and business, and advises the president on the activities in their province.
According to the Constitution of the AFM in Zimbabwe, the election of the President takes place during the workers' council with equal representation from all the provinces (they are called the Electoral College) during the election year (Constitution 13.1.1, p. 29). The candidate is selected from the overseers of the provinces. Like the overseer, he (up till now male only) also remains as the pastor of an assembly while he is leading the whole church. According to the Constitution 13.3, p. 30, the president has the overall supervision over the overseers, pastors and all departments of the church. The president is the head of the whole church and chairs the Apostolic Council, the church's highest governing board. The position of the president is the highest position in the AFM in Zimbabwe and the president, as a pastor, is a full-time employee of the church.

According to Banks and Ledbetter (2004:42), those in Pentecostal leadership should understand that 'leadership begins with understanding that one is a follower of Jesus and a vessel for the power of his Spirit. God is the chief leader who chooses human leaders'. The AFM leadership in Zimbabwe is therefore no different from others who look only to God. The fact that Pentecostals believe that God baptises people with the Spirit is an indication to them that leadership is from God. They believe that leadership is 'transportable, adaptable and personal' (see Banks \& Ledbetter 2004:47). Leadership in the AFM in Zimbabwe is therefore a development that is seen as being in continuity with biblical leadership. However, the individuals in the church's leadership are often viewed with suspicion, especially for the way in which the gender imbalances are perpetuated in the church's leadership. The AFM in Zimbabwe, governed by the Constitution, strictly adheres to certain qualifications and expectations before a person can pass the scrutiny to become a leader in the church. An analysis of the Constitution's list of qualifications is necessary to understand the AFM's requirements for their leadership candidates. The elders and the deacons in the AFM are examined spiritually and physically in order to pass their leadership entrance. The church uses two key Scriptures to accomplish that. These are 1 Timothy 3:1-13 and Titus 1:5-9 (Constitution 4.5.1).

\section{The election of leaders in the Apostolic Faith Mission in Zimbabwe}

The AFM in Zimbabwe elects leaders through a process of voting. A person who is elected becomes a leader in the particular area in which they work. The mode of election is that candidates are first nominated and then voted for by the voters' college by show of hands. The voters' college initially consisted of the church board members of all the assemblies. This was later amended to only 10 members from a province. It is the task of the overseer and his committee to select the members of the voters' college. This voting system is based on Acts 1:23-26 where the apostles had to find a replacement for Judas. In this example of casting lots, only men were 
considered to be eligible candidates. In effect, the exclusion of women amounts to those persons with the power to decide directing God to endorse their choice, rather than all the people of God being available to God to choose from and make known to people through their prayers. It is clear from how the apostles proceeded with the selection of the two men, who their preferred candidate was. The candidates were in effect selected by the people and not by God. This electoral system automatically excluded women because it started out by providing the male candidates from whom people could choose. The process was therefore not surrendered wholly to God. Had the patriarchal cultural system not dictated the process, women as half of God's creation and half of the community of believers, might have been in picture.

Although a woman can feel called to express her gifts of leadership in the church, she will most probably encounter resistance. The voice of women at the senior levels of leadership is not strong. It takes a great deal of courage and a clear sense of calling for women to make it to the table where key organisational and developmental decisions are made (see Banks \& Ledbetter 2004:29). Though the 'voters' college' of the AFM in Zimbabwe includes women voters, the college is 'not allowed' to vote for them. Gender bias is the main factor that slows down female advancement in the church even though there are women who are gifted and equally capable of being a leader.

\section{Leadership styles in the Apostolic Faith Mission in Zimbabwe}

There are a number of leadership styles according to which church leaders operate as they direct and influence the group. The following three styles of leadership will be discussed and evaluated for application in the AFM in Zimbabwe: democratic, laissez-fare and autocratic. Each style has its own advantages and disadvantages with regard to the development of the church.

Democratic leadership, as explained by Gastil (1994:953), is also known as participative leadership. For the AFM in Zimbabwe, this leadership style is appropriate because the members participate in the decision-making process, and there is a significant amount of power in the hands of lay persons. Some leaders in the AFM in Zimbabwe do adopt this leadership style because it can contribute to higher productivity and better participation from the members than other leadership styles. It can also lead to an improved group morale because members are involved and encouraged to share their ideas and opinions. The leader or pastor does, however, retain the final say when it comes to decisions. This is often seen as the preferred leadership style in the AFM in Zimbabwe. Members generally prefer to participate rather than just being observers. This style of leadership can be adopted by any leader regardless of gender. When the congregation is actively involved, creativity is encouraged and rewarded.
Many men still do not accept a woman 'above' them. Also, in the AFM in Zimbabwe, women have not yet found it easy to break new ground in the church's top leadership. Some men are in favour of women in the ministry and opine that to deny women the privilege of service on some levels of the church will distort the gospel and impoverish the church and its development agenda. As women are the majority, a democratic leadership style should include their voices. This style of leadership encourages all members to share their thoughts. Democratic leadership can therefore lead to generating innovative ideas and creative solutions from the broad spectrum of the membership. Some members of the church are intellectually capable and can advise the leadership well.

This would enhance development. Although democratic leadership is ostensibly the preferred style of the AFM in Zimbabwe, the church is not consistent in its chosen style. The local board still is dominant rather than that the contributions of all carry equal weight.

While roles are unclear or time is pressing, however, democratic leadership can lead to a failure of communication and incomplete projects. This can disrupt development. It is also possible that the members of the group do not have the necessary knowledge or expertise to make quality contributions to the decision-making process. A democratic leadership style would therefore work best where the members of the church are educated and knowledgeable. In the case of the AFM in Zimbabwe, cultural norms and values play a role in the way in which leaders see their role and execute their duties. The position of the AFM leaders regarding female leadership in the top positions is based more on African culture than on a biblical understanding. It is easy to find biblical texts that support patriarchal structures and leadership. Therefore, the challenge for the AFM in Zimbabwe with regard to women in leadership roles would be to acknowledge the role of culture. Although the AFM in Zimbabwe is purportedly 'democratic', where gender is concerned, this 'democracy' is overshadowed by culture. Hence, women in the AFM in Zimbabwe are fighting a cultural war for their freedom from male dominance that has held them prisoner for so long.

The laissez-faire leadership style is also known as 'delegative leadership'. It is a style of leadership in which leaders follow a hands-off approach and allow group members to make the decisions. According to Saungweme (2012:34), this is the leadership style that generally results in the lowest productivity among group members. In laissez-faire leadership, there is very little guidance from leaders. It provides complete freedom for the followers to make their own decisions. The leaders only provide the tools and resources that are needed for the followers to proceed. In this style of leadership, the members are expected to solve problems on their own. On the one hand, this style of leadership can be effective in situations where group members are highly skilled, motivated and capable of working on their own. The laissez-faire style is a hands-off 
approach. Leaders remain open and available to group members for consultation and feedback. This style of leadership is not ideal in cases where group members lack knowledge or expertise for completing their tasks and coming to decisions. Some people are not good at setting their own deadlines, managing their own projects and solving problems on their own. Saungweme (2012:35) emphasises that in such situations, projects can go off track and deadlines can be missed when team members do not receive sufficient guidance or feedback from leaders.

For all of these reasons, this style will not work in a congregational structure such as the AFM in Zimbabwe.

The autocratic leadership style is also known as 'authoritarian leadership'. It is a leadership style characterised by individual control over all decisions and little input from group members. Autocratic leaders typically make choices based on their own ideas and judgements and rarely invite or accept advice from followers.

Autocratic leadership involves absolute, authoritarian control over a group. This leaves the group with little or no input regarding matters that may affect them in the community or the church. In this style of leadership, leaders make decisions by themselves. However, to function well, executing the decisions may need the engagement of the congregation. Such leaders dictate the work, methods and processes, and members are rarely trusted with decisions or important tasks. Although this is not the official choice, this style can be found in the AFM in Zimbabwe. Especially those with a political agenda tend to adopt this style because it provides them with virtually unlimited power.

While this style of leadership is in operation, decisions are made quickly and without consulting the group.

While the leader has a specific agenda, some members can be appointed by the leader to implement that agenda.

While this style can be beneficial at times, it is open to the abuse of power. People who abuse an autocratic style of leadership are often experienced as being dictatorial and controlling. This can lead to resentment among group members. Because autocratic leaders make decisions without consulting the group, people in the group often dislike the decisions. They also dislike their powerlessness to contribute ideas. Autocratic leadership leads to a lack of creative solutions to problems. This can ultimately impair the performance of the group. While autocratic leadership does have its pitfalls, leaders can learn to use elements of this style of leadership wisely.

For example, the AFM in Zimbabwe can use this style effectively in situations where the leader is the most knowledgeable member of the group or has access to information to which the members do not have access.

Some leaders in the AFM in Zimbabwe have adopted an autocratic leadership style in different ways. Some ask for the input of followers but do not do anything constructive with their contribution. Instead, they often use the information to engage in church politics. In the process of gathering information from the followers, leaders who are suspicious and who do not have confidence in their followers regard the feedback that was intended to make a positive contribution to the growth of the church, as an effort to oust them. These kinds of struggles are ongoing and this also has an impact on women. Women are often dismissed as the 'weaker vessels' where men battle for personal power. In all of this, there is not much evidence of the core values of the gospel or spirituality. Autocratic leaders tend to demand recognition for themselves rather than giving themselves in service to the people and God. True leadership is a form of servanthood. According to Matthew 20:27, Jesus says: '... and whosoever will be chief (principal, leader) among you, let him be your servant ...' This aspect is embodied in Jesus who is ultimately the role model and head of the church (Heb 12:2-3). The integrity of those who say that they follow Jesus cannot be compromised.

\section{Leadership succession in the Apostolic Faith Mission in Zimbabwe}

Leadership succession is 'the change of a leader as a result of among other things, promotion, death or sickness' (Saungweme 2012:37). The AFM in Zimbabwe has a 'call system' for succession when a pastor moves from one congregation to another or dies. According to the Constitution (15.15-15.25, pp. 34-35), when a local board of elders desires that a pastor moves to their assembly and be their chairperson and shepherd, they request the Provincial Committee in writing to call the pastor on their behalf. This process also involves the Apostolic Council, the church's highest governing board, intimating the intention of the move to the local church board through the Provincial Committee. It is the prerogative of the local church board to call any pastor they prefer. Those women, who are called, are mostly called by church boards that are gender-sensitive and nonpatriarchal. Such an attitude, however, is not yet found in the majority of the congregations of the church.

After the board of elders has requested the Provincial Committee to call the pastor on their behalf, the Provincial Committee ascertains whether the call is in order. A letter is then sent by the Provincial Committee to the pastor who is called. The pastor can refuse the call. Should the pastor respond positively to the call, he or she replies to the assembly board through the Provincial Committee. Usually, only a pastor who has worked at an assembly for 2 years would be eligible for transfer or to accept a call to another assembly. Succession or change of leadership has its advantages and disadvantages. This is the case in the AFM in Zimbabwe as in any other organisation (see Saungweme 2012:37). The system can be abused and become a politically motivated succession system.

Succession improves organisational progress when a new leader brings fresh ideas that change the present state of affairs for the better. Overstaying one's welcome at a specific 
place can lead to complacency, which can affect the progress of the church. If, for instance, many proposed projects were started but not completed because of the reluctance of the leader, but a new person comes with fresh ideas and the zeal to achieve the goals, this can shift the progress of the assembly. If a president of the church takes on a second term of office without bringing about any development or taking the church to a next level, this can cause the church to become stagnant.

There is no causal relationship between succession and organisational performance. The church has to identify the relationship between its organisational need and the performance of its leaders (see Clegg et.al. 2005:88). In its selection of individuals for the church's leadership, it is unwise and goes directly against the gospel message of inviting all to become fully functioning and contributing members of the body of Christ according to their God-given gifts and calling, to exclude more than half of the talent by focussing only on male leaders as possible candidates. Rather, the performance of individuals, who can also be females, should be appraised realistically. If this relationship is not assessed accurately, it can affect the church's growth negatively, on the one hand, and perpetuate gender bias on the other hand. With a focus on the guidance of the Holy Spirit rather than on power, position and politics, the inspired contribution of all members of the body of Christ can be cherished.

\section{Conclusion}

The AFM in Zimbabwe has in effect excluded women from the higher echelons of its leadership structures, among others, by using gender-exclusive language in its constitution. As women have been ordained in the church, since 1999, the old constitutional language is no longer useful. Now, women pastors are present in the leadership of the church. There has been a fair inclusion of women and a positive development in the leadership of the local assembly. On the higher level of leadership, namely, the Provincial Committee, and the highest level of leadership, namely, the Apostolic Council, the same cannot be said. Given the complicated mixture of the church's episcopal and Presbyterian leadership as well as the different leadership styles adopted by those in power, there are quite a few possibilities for excluding women from full participation, especially when it comes to higher leadership positions. On the grassroots level, a female pastor, though the chairperson of the local church board, has to defer to the power and decisions of the elders in the assembly. The elders can engage the congregation and come to an unfavourable decision regarding the pastor. In this way, the pastor can be affected by the decisions of the board. On the higher level of the Provincial Board, where the power lies with the overseer who is a pastor, the way in which the overseer is elected does not leave much space for a woman to attain the position because of the voting system where she again is powerless. This is also the case at the national level of leadership where the president is chosen from the pool of provincial overseers. Although there is no explicit impediment to women rising to positions of higher leadership, the church' gender bias is clear in the exclusive male language of the constitution. That is accepted without question and perpetuated even decades after women were first ordained in the church. The patriarchal culture in both church and society contributes to ensuring that male leadership remains dominant in the church's highest offices. This has been the case since the inception of the church in Zimbabwe around 1915. This was also the case when black male leadership took over, with Langton Kupara as the first Superintendent around 1930. This is still the case today. Yet, the inclusion of women in leadership is critical to ensure that the AFM develops fully as the people of God and contributes fully to development in Zimbabwe. By utilising women's God-given leadership abilities, the AFM can, for instance, contribute towards eliminating poverty and improving the quality of life for the majority of the people in the country. If women, who have the advantage of numbers, make that count and step forward to offer their gifts, talents and skills, and if men become willing to see and acknowledge the injustice of the present situation, all can work together to rectify the gender imbalance and exclusion that is still prevalent in the church. For this, awareness and courage are needed.

\section{Acknowledgements}

Organisational leadership, women and development in the Apostolic Faith Mission in Zimbabwe.

\section{Competing interests}

The author declares that they have no financial or personal relationships which may have inappropriately influenced them in writing this article.

\section{Authors' contributions}

All authors contributed equally to this work.

\section{Ethical considerations}

This article followed all ethical standards for carrying out research without direct contact with human or animal subjects.

\section{Funding information}

This research received no specific grant from any funding agency in the public, commercial, or not-for-profit sectors.

\section{Data availability statement}

Data sharing is not applicable to this article as no new data were created or analysed in this study.

\section{Disclaimer}

The views and opinions expressed in this article are those of the authors and do not necessarily reflect the official position of any affiliated agency of the authors. 


\section{References}

Banks, R. \& Ledbetter, B.M., 2004, Reviewing leadership: A Christian evaluation of current approaches, Baker Academic, Grand Rapids, MI.

Clegg, S., Kornberger, M. \& Pitsis, T., 2005, Managing and organisations: An introduction to theory and practice, SAGE, New Delhi.

Daneel, M.L., 1989, Fambidzano: Ecumenical movements of Zimbabwe independent churches, Mambo Press, Gweru.
Gastil, J., 1994, 'A definition and illustration of democratic leadership', Human Relations 47(8), 953-975. https://doi.org/10.1177/001872679404700805

Posner, K., 2002, The leadership challenge, Jossey-Bass, San Francisco, CA.

Powers, B.P., 1979, Christian leadership, Broadman Press, Nashville, TN.

Saungweme, M., 2012, Sociology of organizations: Module SS213, Women's University in Africa, Harare.

Titus, C.H., 1950, The process of leadership: Human relations in the making, WMC Brown, Dubuque, IA. 